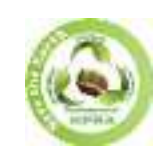

Research Paper

EPRA International Journal of Economic and Business Review-Peer Reviewed Journal

Volume - 9, Issue - 6, June 2021 | e-ISSN: 2347 - 9671| p- ISSN: 2349 - 0187

SJIF Impact Factor (2021): 8.302 || ISI Value: 1.433 || Journal DOI URL: https://doi.org/10.36713/epra2012

\title{
APPLICATION OF THE COMPREHENSIVE TOTAL QUALITY MANAGEMENT ON KING KHALID UNIVERSITY IN SAUDI ARABIA
}

\author{
${ }^{1}$ Nidaa Abdulwahab Arishi, ${ }^{2}$ Maged Mustafa Al-Dubai \\ ${ }^{1}$ Al-Madinah International University, Kuala Lumpur, Malaysia \\ ${ }^{2}$ Al-Madinah International University, Kuala Lumpur, Malaysia
}

This study aims to study the Comprehensive Total Quality Management On king Khalid University In Saudi Arabia to better performance. The main problem is that quality standers from one time to another are changeable, and universities should update the quality system to enhance organizational performance. For data analysis and hypothesis testing, the S.E.M. tool and several statistical methods such as the maximum likelihood estimate and regression technique will be utilized to understand the dimensionality of the variables. Based on research findings, theoretical and practical implications will be discussed. Limitations and recommendations for future research were also highlighted.

KEYWORDS: Total Quality Management, Quality System, Organization Performance.

\subsection{INTRODUCTION}

The application of total quality management in university education institutions needs enormous material resources for the rehabilitation and training of personnel and the provision of appropriate means and methods to be applied. They need to long for the application to take advantage of them. Therefore, all responsible actors in society in funding in university education institutions and everything necessary to apply total quality management.

Here, the study thinks that the application of total quality management in university education institutions through better performance and improve the functionality of the King Khalid University requires full conviction by the senior management of the university community. The environment and students further the importance of achieving the objectives of the university through the application of quality management to provide all appropriate means and material and human resources and scientific cooperation of all the parties to the university education and administrative process in terms of building a culture of conscious knowledge of the concepts of management in the overall quality and the extent of its

(c) 2021 EPRA JEBR | EPRA International Journal of Economic and Business Review I www.eprajournals.com 
contribution to the development of the administrative work and university education in university education institutions, and how important it is to obtain the highest level of service.

\section{RESEARCH QUESTION}

From here, you can determine the problem of the study in the following fundamental question.

What is the influence of measurement and evaluation on organizational performance in King Khaled University?

\section{RESEARCH OBJECTIVE}

To investigate the influence of measurement and evaluation on the organizational performance in King Khaled University.

\subsection{LITERATURE REVIEW}

The study provides an evaluation of this program to improve university education entrance job performance by comparing his philosophy as theory and research organization change processes in general and the reform of the university in particular, it was noted that the entrance of Total Quality Management as a tool to improve the University program, and study the calendar of operations, and the compilation of information based on the adoption of the resolution, and improve systems, continuous learning, improving performance in the administrative work and teachers, all aspects of the implementation of the force when he noted that the negatives were in the political nature of the university, the difficulty of identifying the recipients of the service, and the difficulty of change in the existing culture and waste time, lack of funding, the obstacles to impede the operations of the improved performance , the survey provided a set of proposals In the theoretical framework of the future and discussed the functions of the entrance of the total quality management (T.Q.M.) as the program to improve educational performance.

\subsection{Gap analysis}

Based on this debate, the current study tries to formulate a complete model that practitioners can adopt following their validation in Saudi Arabia as part of the king Khaled university by adopting new variables to enhance the quality, which will eventually help improve the organizational performance. This study will try to fill this gap by evaluating and validating these significant aspects.

\subsection{UNDERPINNING THEORIES}

Each study shall be based on specific theories supporting the reason and benefits of the study. Thus, justifying the selection of the topic and the variables of the study.

\section{Theory of Performance}

This theory is describing the performance generally in term of aspects, concepts, and dimensions, and explaining the performance evaluation and assessment with the most influential factor on the organizational performance which it's the human resource (Al-Dubai et al., 2019; Al-Dubai \& Gopalan 2019; Khasawneh, S. N., Mohamed, H. B., \& Al-Dubai Sonnentag\&Frese, 2002). In the same study, the authors summarized organizational performance as the outcome aspect refers to the consequence or result of the individual's behaviour.

Several theories are grounding the general theory of performance embodied in motivation theories, human capital theories, and other relevant theories (Aryee et al., 2016). Some other researchers regarded performance appraisal as the primary and most crucial theory affecting organizational performance. In contrast, evaluating the performance includes a summary of the weaknesses and strengthening of the organizational performance, which might help the organization improve the total performance (Evans \&Tourish, 2017).

Therefore, another study stated the importance of performance theory in improving the administrative activities and involving the management in the conditions of the organization to create up a team working out on better situation and environment toward success (Tomaževič, Tekavčič, \&Peljhan, 2017).

Senior management must be fully convinced of the importance of total quality management to improve the quality of service and the rational use of human and material resources. And then through the guidance of the senior management to improve the functionality of the administration could be the application of total quality management at the university because the presence of the leadership and the determination to improve the administrative process and develop a vision for the future is the level of quality in enhancing job performance.

\section{Theory of Total Quality Management}

Since the 1980s, Total Quality Management (TQM) has been considered one of the most popular management philosophies/ theories by which enterprises enhance their management capabilities, improve performance, and achieve quality and excellence (Fu et al., 2015). Often defined as a holistic management philosophy, TQM seeks to continuously improve products and processes by achieving continuous organizational improvements and exceed customers' expectations - among other benefits through everybody's participation (Chen et al., 2016). 
The TQM building mindset is created by continuous training and building up new practices, and maintaining behaviour, motivation and attitudes needed for implementing TQM principles, tools and techniques in daily working life.

The principles of TQM have evolved through remarkable contributions of renowned quality pioneers, such as W.A. Shewhart, W. Edwards Deming, Joseph M. Juran, Armand Feigenbaum, Philip B. Crosby, Kaoru Ishikawa, Genichi Taguchi, and Shigeo Shingo, who have all played essential roles in building TQM (Ritchie \& Dale, 2000). These authors emphasized continuous improvement through everybody's participation and needed to lead the whole company effectively and efficiently to meet customer needs and expectations. Many quality experts, associations, and companies worldwide have provided models to foster a better understanding of how the mechanism for improving organizational management works. For example, Peter's and Austin's Simple Model of Excellence of, the Xerox Business Excellence Models, the 4P model of the Toyota production system [T.P.S.], the EFQM/European Excellence Model, and the 4P Excellence model for building organizational excellence (Dahlgaard-Park \&Dahlgaard, 2007).

Analysts have credited Japan's post-war economic recovery to TQM, considering its holistic and systematic management philosophy with many valuable tools and techniques.TQM has been regarded as one of the most inspiring sources for developing modern management theories and a conceptual and practical backbone for designing the various management models mentioned above. These management models have often been produced by organizations, consultants, or theoreticians to operationalize, implement, practice, perform, and assess TQM principles, tools, and techniques (Dalsgaard, Reyes \& Chen, 2018).

The theory concerns the abilities of the economies and countries to hit the best product and services. It is including each simple detail and activity in the economy (Kipngetich\&Bett2018). This is generally about the function and uses of total quality management in the companies. These companies should implement and practice comprehensive quality management to be following up in the current economic development (Fulop\& Lilley 2014). Total quality management is one of the most important contributors in the organizational earning, as the leading implemented theory to achieve higher profit and effective performance (Al-Dubai, M. M., \& Alaghbari,2018; Beyer, Guttman, \&Marinovic, 2018; MM, A. D., \& MM, A,2018)).

Total quality management is needed for modern technology and systems to be professionally practiced in firms. As well, comprehensive quality management nowadays is all about improving the production lines, products, saving costs, and producing the competitive goods to the market,

accordingly, to provide such outcomes to the market, the organizations have to use the information systems and the latest technology (Khanam, Siddiqui, \&Talib, 2016).

In the higher education system, total quality management has been studied and reported as necessary and needed in the educational system in America; the study concludes that there is a need to use the modern total quality management system instead of the traditional method (Hickman\&Akdere, 2017). There are specific strategies that shall be followed to achieve the excellence of quality management and achieve better performance, stated that there is a model of three dimensions of the approach of quality management to be implemented toward the success of the organization (AL'AS, F. A., Alhety, S., \& AlDubai, 2020; Alhasheedi, Bin, \& Mustafa 2020; Alhashedi et al., 2021; Altanashat, M., Al Dubai, M., \& Alhety 2019; Androniceanu, 2017).

\subsection{RESEARCH METHODOLOGY}

The study intends to use a cross-sectional survey design in determining the leverage on mobile payment methods to gain a competitive advantage by locally based businesses. The study will sample 478 local based businesses registered in Kenya out of a population of 4 thousand which are mainly registered and operated in village area settings.

The study intends to use a cross-sectional survey design in determining organizational performance. A quantitative study will be used as a data collection method to distribute among university employees. More than 130 questionnaires will be collected. The study will collect both primary and secondary data, and the quantitative data generated will be analyzed using descriptive statistics, including percentage distribution, mean and frequency counts. The project is expected to be completed in 17 weeks, including data collection and analysis.

The study will collect both primary and secondary data, and the quantitative data generated will

be analyzed using descriptive statistics, which will include percentage distribution, mean and the frequency counts

\subsection{THEORETICAL IMPLICATIONS}

The theories of this study embodied a theory of performance and theory of total quality management increase the productivity of the organizations and improve the entire performance in the firms. Performance theory is essential and implemented in every firm because it is mainly the target of each 
institution to positively affect the industries, countries, and societies. The theoretical base is required to draw down the university's path in the following years and where the university is willing to go. This all could happen if the university focuses on a point to be achieved. Through implementing the theoretical base, there would be further suggestions and ways to achieve the targets.

\subsection{Practical Implications}

University is recommended to focus more on organizing training programs for the employees and encouraging them to continue their study to acquire further knowledge and add value to the university. Indeed, the more knowledgeable the employees are, they will support the university in proceeding with modern education and adopting the latest methods to be different in the education industry. Especially in Saudi Arabia, citizens are more concerned about education nowadays and ambitious to reach advanced levels of education, which could help the country and economy be among the best in the world. I

\subsection{CONCLUSION}

Education and training influence organizational performance by increasing the university's knowledge base, which could improve the whole country's knowledge base. This research will help King Khaled University implement these factors in the university and be among the management's concerns. Thus, to better the university's organizational performance, it could achieve the university's targets and improve the university's accomplishment in the upcoming years.

\section{REFERENCES}

1. Al-Dubai, M. M., \& Alaghbari, M. A. (2018). Relationship between organizational factors toward project success. Journal of Internet Banking and Commerce, 23(2), 1-21.

2. Al-Dubai, M. M., \& Gopalan, V. (2019). Mediating role of Leadership styles on the relationship between recruitment and selection and employee satisfaction among telecommunication employees. Journal of Internet Banking and Commerce, 24(2), 1-11.

3. Al-Dubai, M. M., Gopalan, V., Alaghbari, M. A., \& Hamood, A. M. (2019). FHE MODERATING ROLE OF JOB SATISFACTION ON THE RELATIONSHIP BETWEEN HUMAN RESOURCE MANAGEMENT PRACTICES AND EMPLOYEE PERFORMANCE $A M O N G$ TELECOMMUNICATION EMPLOYEES. Journal of Internet Banking and Commerce, 24(3), 1-22.

4. Alhashedi, A. A. A., Bardai, B., Al-Dubai, M. M. M., \& Alaghbari, M. A. (2021). Organizational citizenship behavior role in mediating the effect of transformational leadership on organizational performance in gold industry of Saudi Arabia. Business: Theory and Practice, 22(1), 39-54.

5. AL'AS, F. A., Alhety, S., \& Al-Dubai, M. M. (2020).

THE RELATIONSHIP BETWEEN HUMAN

CAPITAL DEVELOPMENT AND ORGANIZATIONAL PERFORMANCE IN THE TELECOMMUNICATION INDUSTRIES IN YEMEN. International Journal Of All Research Writings, 3(1), 78-84.

6. Altanashat, M., Al Dubai, M., \& Alhety, S. (2019). The impact of enterprise risk management on institutional performance in Jordanian public shareholding companies. Journal of Business and Retail Management Research, 13(3). 7.

7. Alhasheedi, A. A. A., Bin, B. B., \& Mustafa, A. D. M. (2020). The effect of transformational leadership behavior on organizational performance in the gold industry of Saudi Arabia. Journal of Process Management. New Technologies, 8(3), 6281 .

8. Androniceanu, A. (2017). The three-dimensional approach of Total Quality Management, an important strategic option for business excellence.Anfiteatro Economic, 19(44), 61-78.

9. Aryee, S., Walumbwa, F. O., Seidu, E. Y., \&Otaye, L. E. (2016). Developing and leveraging human capital resources to promote service quality: Testing a theory of performance. Journal of Management, 42(2), 480-499

10. Beyer, A., Guttman, I., \&Marinovic, I. (2018). Earnings Management and Earnings Quality: Theory and Evidence. The Accounting Review. doi:10.2308/accr-52282

11. Chen, C.-K., Anchecta, K., Lee, Y.-D., \&Dahlgaard, J. J. (2016). A stepwise ISO-based TQM implementation approach using ISO 9001: 2015. Management and Production Engineering Review, 7(4), 65-75.

12. Dahlgaard-Park, S. M., \&Dahlgaard, J. J. (2007). Excellence-25 years evolution. Journal of Management History, 13(4), 371-393.

13. Dahlgaard-Park, S. M., Reyes, L., \& Chen, C.-K. (2018). The evolution and convergence of total quality management and management theories. Total Quality Management \& Business Excellence, 29(9-10),

$1108-1128$ doi:10.1080/14783363.2018.1486556

14. Dahlgaard-Park, S. M., Reyes, L., \& Chen, C.-K. (2018). The evolution and convergence of total quality management and management theories. Total Quality Management \& Business Excellence, 29(9-10),

$1108-1128$ doi:10.1080/14783363.2018.1486556

15. Evans, S., \&Tourish, D. (2017). Agency theory and performance appraisal: How bad theory damages learning and contributes to bad management practice. Management Learning, 48(3), 271-291.

16. Fu, S.-L., Chou, S.-Y., Chen, C.-K., \& Wang, C.W.(2015). Assessment and cultivation of total quality management organizational culture-An 
empirical investigation. Total Quality Management \& Business Excellence, 26(1-2), 123-139.

17. Fulop and Lilley. (2014). the impact of quality management practices on performance and competitive advantage, Decision Sciences, 26(5), pp. 659- 691.

18. Hickman, L., \&Akdere, M. (2017). Stakeholder theory: Implications for total quality management in higher education.

19. Khanam, S., Siddiqui, J., \&Talib, F. (2016).Role of information technology in total quality management: a literature review. Khanam, S, Siddiqui, J. and Talib, F.(2013), "Role of Information Technology in Total Quality Management: A Literature Review," International Journal of Advanced Research in Computer Engineering and Technology, 2(8), 2433-244

20. Khasawneh, S. N., Mohamed, H. B., \& Al-Dubai, M. M. (2020). THE MODERATING ROLE OF TALENT MANAGEMENT ON THE RELATIONSHIP BETWEEN HUMAN CAPITAL AND INSTITUTIONAL EXCELLENCE IN THE GOVERNMENT SECTOR IN THE EMIRATE OF $A B U$ DHABI. International Journal Of All Research Writings, 3(1), 1-11

21. Kipngetich, K. M., \&Bett, S. (2018). Total quality management practices and performance of Savannah Cement Limited, Kenya. International Academic Journal of Human Resource and Business Administration, 3(4), 54-80.

22. MM, A. D., \& MM, A. (2018). Evaluating the role of project team factors in determining the project success: Scale validation. Journal of Internet Banking and Commerce, 23(2), 1-12.

23. Ritchie, L., \& Dale, B. (2000). Self-assessment using the business excellence model: A study of practice and process. International Journal of Production Economics, 66(3), 241-254.

24. Sonnentag, S., \&Frese, M. (2002).Performance concepts and performance theory. Psychological management of individual performance, 23(1), 325.

25. Tomaževič, N., Tekavčič, M., \&Peljhan, D. (2017). Towards excellence in public administration: organization theory-based performance management model. Total Quality Management \& Business Excellence, 28(5-6), 578-599 